\title{
Social and Cultural Images of Qajar-Iran Customs in European Travel Diaries
}

\author{
Zahra Talaei Hatam ${ }^{1}$, Foad Pour Arian ${ }^{1}$, Khadijeh Salimi ${ }^{2}$ \\ ${ }^{1}$ School of Humanities and Literature, Kharazmi University, Karaj, Iran \\ ${ }^{2}$ School Of Art and Letter, Old Dominion University, Norfolk, USA \\ Correspondence: Khadijeh Salimi, School Of Art and Letter, Old Dominion University, Norfolk, USA. Tel: \\ 1-757-201-0329. E-mail: niloufarsalimi@yahoo.com / ksali001@odu.edu
}

\author{
Received: March 5, 2015 Accepted: March 10, 2015 Online Published: April 21, 2015 \\ doi:10.5539/ach.v7n2p29 URL: http://dx.doi.org/10.5539/ach.v7n2p29
}

\begin{abstract}
One of the most important sources for studying the social and cultural situation of Qajar Era is the travelogues written by European travelers. The objective of present paper is to study reaction of European travelers to the customs of Qajar Era, compare customs changes of that period with current Era and identify factors affecting custom changes trajectory. Moreover, it is assumed that some of the European criticizes Iranian culture when faced their customs. Customs related to celebrations and mourning are changed significantly since Qajar Era and it is known that social and political changes along with globalization issues are effecting evolution of customs. The method of collecting the data of this study is library method and is based on analytical and descriptive method. While identifying and introducing an 8-factor model effective on culture change, the important role of social and cultural changes and globalization in culture change and changes of customs has been confirmed.
\end{abstract}

Keywords: Qajar Society, culture, customs, reaction, travels diaries

\section{Introduction}

A custom is anything which lots of people do, and have done for a long time. Usually, the people come from the same country, culture, time or religion. If something is usually done the same way, you might say that is the "customary way" of doing things. The meaning of culture is similar to the meaning of custom. A custom is more about practices, while culture is more about ideas or a group of customs. A custom overall is just similar to culture and culture means the way of life of a people (Custom, 2015).

Each nation and tribe has its own customs that are emerging in their happiness, sorrow, mourning and their mutual relations which are respected and valuable among that nation and it has social, cultural, and religious support. Customs are considered as the subsets of a culture and it is clear that development and evolution of society are drastically related to its cultural sublimity. As one of the civilized countries during the history, Iran is not an exception from this rule and has its own customs and traditions.

Foreign Affairs of Iran with European countries developed since Safavid Dynasty and lots of Europeans entered Iran with different aims such as political missions, tourism, to get familiar with Iran culture and etc. In Qajar Era for various reasons this affairs developed and entrance of European increased. Agha Muhammad Khan, which is the beginning of the Qajar Dynasty Era, has rarely seen any foreigner entering the country. The ruling period of Fath-Ali Shah was contemporaneous with emergence of Napoleon Bonaparte in France and his competition with United Kingdom; therefore, both countries noticed Iran, which was one of the paths towards India. They tried to strengthen ties with Iran through sending their ambassadors. Since this period, Europeans' entrance and their interventions in internal affairs of Iran increased. This process continued in Mohammad Shah period too. In that time, the issue of Herat Siege by Mohammad Shah that threatened British interests led to occupying of Kharg Island by them. Entrance of Europeans reached its peak in Nasir Al-Din Shah Era. Political purposes outweigh the other aims during pervious Era, but in this period, different purposes encouraged travelers to come to Iran. The time period between Mozafar Al-Din Shah ruling and Qajar Dynasty extinction too, some ambassadors had entered the country, which mostly had political missions. Most of these travelers and officers wrote their memories and their mission reports fully described and in detail. These reports can be categorized into Travel Dairies and biographies and mostly have become famous in the name of their authors. 
The principal objectives of this study is to examine the reaction of foreigner travelers to customs and traditions, comparing changes of Qajar Era with current Era and also define and state effective factors in evolution of this customs. In this study it is assumed that some of the Europeans had a critic view when faced Iranian customs and traditions, and also customs related to celebrations and mourning have been changed a lot since Qajar Era. Moreover, social and political changes along with globalization are effective in terms of custom and tradition evolution.

This research studied celebrations and mourning of Iran in two main categories of religious and nonreligious ones through library method. After studying the most important itineraries of Europeans in Qajar Era, the reaction of travelers to the customs and traditions of people of this Era has been studied in two sections of positive and negative reactions. Afterwards, referring to different books, newspapers, articles and various websites and current tradition and customs' norms the amount of changes in tradition and customs since Qajar Era have been discussed. In the third part, the authors have tried to introduce the factors affecting these changes and state these changes in a diagram. Finally, after stating findings and main objectives of the study, limitation of the study has been stated and appropriate titles and subjects for future researches have been presented. In the final stage, researchers have stated the general results of the study.

\section{Materials and Methods}

The area of this study is limited to Qajar Dynasty which its ruling kings were Agha Muhammad Khan, Fath-Ali Shah, Mohammad Shah, Naser Al-Din Shah, Mozafar Al-Din Shah, Mohammad Ali Shah, and Ahmad Shah. Besides, in this research celebrations and mourning of Iran in Qajar Era will be studied in two main categories of religious and nonreligious ones. Nonreligious celebrations include Nowruz $\mathrm{Eve}^{\mathrm{Note}}{ }^{1}$, wedding, child birth celebration, circumcision celebration $^{\text {Note }}{ }^{2}$; and religious celebrations include religious eves such as Ghorban, Ghadir, and Fetr. Religious mourning mentioned in this study is mourning of Muharram ${ }^{\text {Note } 3}$ and nonreligious mourning is mourning for dead people. Initially the reactions of travelers described in two main categories of positive and negative reactions presented in the table. And afterwards evolution process of celebrations and mourning since Qajar Era to current era studied respectively and with regards to documents and papers collected from Parliament Libraries, Iran's Cultural Heritage Organization, Iranology Foundation, newspapers, internet web sites such as SID, Comprehensive Arts Portal, and also with the help of diagrams these results achieved. After that, the effective factors on evolution and changes of culture and Arjunan Theory for achieving these results Arjunan (2010) has been used. He stated that these factors include 1- environmental factors, 2- biological factors, 3- demographic factors, 4-technological factors, 5cultural factors, 6- ideological factors, 7-psychological factors, and other factors.

Based on these factors and by comparing the conditions of Qajar Era with the current Era, the researchers tried to localize the factors stated by Arjunan, and by synchronizing them with the framework of this study, they extracted some factors stated in the findings section. Therefore, researchers have introduced new local factors in the evolution of culture and tradition and presented this finding in a diagram as a new localized model.

\section{Result and Finding}

\subsection{Reaction of Tourist to Customs and Traditions}

Researchers evaluated the reactions of Qajar Era's tourists to customs and traditions of Iranian in two main categories of positive reactions and negative reactions. Customs are one of the issues that foreign tourists of this era notice. Most of the tourists have tried to present accurate and complete reports of the customs and traditions in their itineraries. They have mentioned Nowruz Celebration and celebrations before or after it positively and called it the only national celebrations of Iran that remain since Ancient times and emergence of Islam in Iran could not disrupt it (Richards, 1931), (Brugsch, 1990), (Polak, 1990). They have mentioned that the time of Nowruz Celebration is better than their Christmas and New Year's Eve and believed that the time of Iranians' Nowruz is the same time of winter ending and start of nature revitalization (Shiel, 1984), (Flandin, 1851). Although, there were some cases that Nowruz is criticized in some of the texts. Presence of Dervishes ${ }^{\text {Note } 4}$ in the cities who stood out in front of doors, and caused disturbance for people was mentioned more than other issues in their texts.

Some of travelers are also known Nowruz and its formalities as a factor that imposes enormous costs on families and government (Polak, 1990). Engagement and marriage ceremonies and their various customs and their differences among different nations and tribes repeated in itineraries. They have mostly mentioned this point that Iranian are attached and committed to their Ancient traditions. But among these texts some of the traditions that they condemned can be find. Some of the issues that travelers have mentioned include the concubine issue, early age marriages, lack of noticing to groom and bride desire in this case and forbidding them to know each other before marriage are.

The religious celebrations related to Islam have been also mentioned in the travelers' writings, particularly the Ghorban Celebration which was held more gloriously Brugsch had accompanied people when he watched a camel 
decorated for being sacrificed in the Ghorban Celebration and given them an amount of money as a gift (Brugsch, 1990). Conversely, some travelers had critical views towards the ceremonies (Orsolle, 1974). They claim that the prince who is given the pride of doing sacrificing regards it as a humiliating one. After explaining the ceremonies of Ghorban Celebration, Fraser has expressed his feeling towards it as a "vain ceremony" (Fraser, 1968).

Some travelers who had visited Iran in Muharram in which mourning is held for Imam Hussein, had dealt with the customs, particularly with Ta'zieh ${ }^{\text {Note } 5}$, and pointed to its glory. Many of them have confessed that they were affected by the ceremonies so that they feel sorrows and regrets in their heart. (Wills, 1990) claims that Ta'zieh seems ridiculous to a foreigner who visits Iran for the first time, but after a while when he is familiarized with people's beliefs, s/he will mourn like Iranian people. (Yate, 1987) had ordered his servants to give juice to Imam Hussein's mourners so that they participate in their sorrow and accompany them. But (Feuvrier, 1990) has not enjoyed Ta'zieh and he did not find it interesting. Qama Zani ${ }^{\text {Note }}{ }^{6}$ has been criticized by the travelers (Orsolle, 1974) has criticized it as a "horrible demonstration".

Iranians' mourning customs have been also explained by travelers. Of course, they have often illustrated the customs. They have criticized the act of burying dead bodies in the sacred shrines which were prevalent in Qajar Era, and they consider it as a factor that transmits diseases. As Grothe (1991)put it "this continuous movement between the dead and alive is a serious permanent danger because it transmits diseases in an efficient way". The next matter that the travelers have paid attention to was the conditions of cemeteries in Iran. They have usually criticized that Iranian cemeteries were too depressing and sorrowful, and Iranians do not pay attention to them (Richards, 1931). Table 1 summarizes the reactions of these travelers towards the Qajar Era customs.

Table 1. Travelers' Reactions towards Iranian Ceremonies and Customs

\begin{tabular}{|c|c|c|}
\hline Ceremonies & Positive Reactions & Negative Reactions \\
\hline \multirow{3}{*}{ 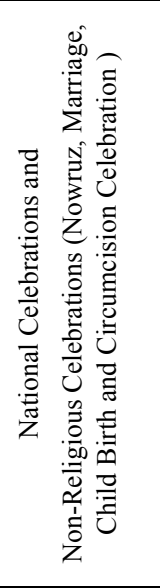 } & $\begin{array}{l}\text { Nowruz Celebration: } \\
\text { - Antiquity of Nowruz } \\
\text { - } \quad \text { The time of holding Nowruz } \\
\text { - Appraising the glory of the ceremonies and people's } \\
\text { enthusiasm for it } \\
-\quad \text { Positive impact of Nowruz in people's moral } \\
-13^{\text {th }} \text { day of Nowruz }\end{array}$ & $\begin{array}{l}\text { Nowruz Celebration: } \\
\text { - Attendance of Dervishes in the city } \\
\text { - The formalities of Salam in Nowruz } \\
\text { - Nowruz visits } \\
\text { - Economic costs of Nowruz formalities }\end{array}$ \\
\hline & $\begin{array}{l}\text { Marriage: } \\
\text { - Ancient formalities } \\
\text { - The foods served at the marriage ceremonies } \\
\text { - } \quad \text { Enthusiasm for holding marriage ceremonies }\end{array}$ & $\begin{array}{l}\text { Marriage: } \\
\text { - Polygamy } \\
\text { - Temporary marriage (Sigheh) } \\
\text { - Marriage at low ages } \\
\text { - The lack of familiarity before marriage } \\
\text { - Patriarchy }\end{array}$ \\
\hline & $\begin{array}{l}\text { Child birth and circumcision celebration : } \\
\text { - Child naming ceremonies } \\
\text { - } \quad \text { circumcision celebration formalities } \\
\end{array}$ & $\begin{array}{l}\text { - Child birth and circumcision celebration, } \\
\text { complain of girl birth }\end{array}$ \\
\hline \multirow{3}{*}{ 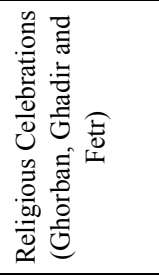 } & $\begin{array}{l}\text { Ghorban: } \\
\text { - Cooperation in presenting the gift for decorated camel in } \\
\text { Ghorban celebration }\end{array}$ & $\begin{array}{l}\text { Ghorban: } \\
\text { - Being none-sense and humiliation }\end{array}$ \\
\hline & $\begin{array}{l}\text { Ghadir: } \\
\text { - Appraising the custom of brotherhood pact }\end{array}$ & \\
\hline & $\begin{array}{l}\text { Fetr: } \\
\text { - Appraising fetrieh (presenting food or money to the poor) }\end{array}$ & \\
\hline \multirow{2}{*}{ 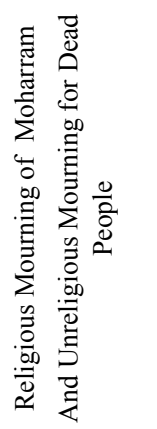 } & $\begin{array}{l}\text { Muharram Month: } \\
\text { - Sincere feelings of people in the ceremonies } \\
\text { - Sympathy for the participants } \\
\text { - } \text { Order in holding the ceremonies }\end{array}$ & $\begin{array}{l}\text { Muharram: } \\
\text { - Being none-sense and boring } \\
\text { - Qama Zani (hitting one's own head by a sword) }\end{array}$ \\
\hline & & $\begin{array}{l}\text { Non-religious mourning: } \\
\text { - Transmitting the dead bodies to sacred places } \\
\text { - Conditions of cemeteries }\end{array}$ \\
\hline
\end{tabular}


Given the mentioned points, we found out that in the European travelogues, Nowruz Celebration is more mentioned in comparison with other celebrations and they have positive views towards it. Often wherever Nowruz and its related observances have been mentioned, the travelers have praised it and criticisms towards it were not mentionable. Among religious celebrations, only Ghorban has been dealt with and other celebrations have been neglected. Marriage customs have been mentioned too and criticism towards these customs is more compared with other ones.

Muharram Mourning ceremonies have been also mentioned by travelers that show these ceremonies held gloriously in Qajar Era. Besides, positive views towards this custom are more compared with negative ones. Also non-religious mourning have been confronted in a neutral way and they have only illustrated them. We can say that one of the factors that itinerant have not dealt with some customs is that they were very pale in Qajar Era.

\subsection{Examination of the Trajectory of Customs from Qajar Era until Now}

We have examined the trajectory of customs from Qajar Era until now in Table 1.

\subsubsection{Nowruz Celebration}

Nowruz is one of the rare celebrations which are still held gloriously. It is even prevalent in other countries of the Middle East and they also regard it as one of their main celebrations. In its session of Mars, the United Nations General Assembly recognized the world day of Nowruz as a celebration by Iranian roots. Even before that date, in September 2009, UNESCO had registered Nowruz as World Intangible Heritage (Ahmadi, 2011). The issue shows the spread and antiquity of this Ancient celebration nowadays. Besides, Nowruz is recognized as an international ceremony.

Nowruz observance had its specific customs in the Qajar Era. People prepared themselves for this celebration by cleaning their homes, growing vegetables at home, and buying sweets and nuts (Hardoui, 1929). People demonstrated their happiness in the last Wednesday of the year Chaharshanbe Suri by lighting fires, jumping over it and dancing (D'Allemagne, 1911). The last Thursday of the year was dedicated to going to cemeteries in order to pay homage to the dead and give charity to the poor (Norden, 1978). In the first day of Nowruz, families prepared Haftsin in which seven things starting with s in Farsi were placed beside Quran, candle, fish, mirror and water (Ibid.). When the guns of New Year were fired, family members embraced each other and wished a happy year for each other. Nowruz Celebration customs held in the king's palace too during which the king congratulated people and officials and held celebration and dancing ceremonies (Polak, 1990), (Feuvrier, 1990), (Flandin, 1851), (Wills, 1990).

Nowruz Celebration continued until thirteenth day in which people went to picnic. According to a superstition, people should go outside in the nature because the day is not blessed and if they will stay home, a bad accident would happen $^{\text {Note }} 7$ (Shiel, 1984). Nowadays most of observances for embracing new year such as growing vegetables, cleaning home, Chaharshanbe Suri (Rooh Al Amini, 1998) and paying homage to the dead in the last Thursday of the year are held (Bahrami, 2005). Chahrshanbe Suri does not belong to a particular religion or ethnic group, and it is popular among most of Iranians. Of course, in recent years, the troubles related to using bonfire and explosive materials have increased and the media pays attention to the matter in order to increase awareness about it (Jafari Nia \& Yegane, 2014) Like the Qajar Era, many people still pay homage to the dead in cemeteries. In the first day of Nowruz, Haft-Sin is prepared and family members embrace each other when the New Year moment is announced. As one of the most important cultural aspects of Iranian culture, Sizde-bedar is held in all towns and villages in the same way (Shabani, 2001). It is necessary to point that although many customs are sustainable but their observances is paler than before and some of them have changed. For instance, nowadays Nowruz visits are paler but Nowruz trips are more obvious than before. The factors for this change includes: The spread of Cities, increasing population, socioeconomic developments, dispersion of traditional families, job limitations, and apartment life (Rooh Al Amini, 1998). Figure 1 illustrates the figures of trips in the last six years. 


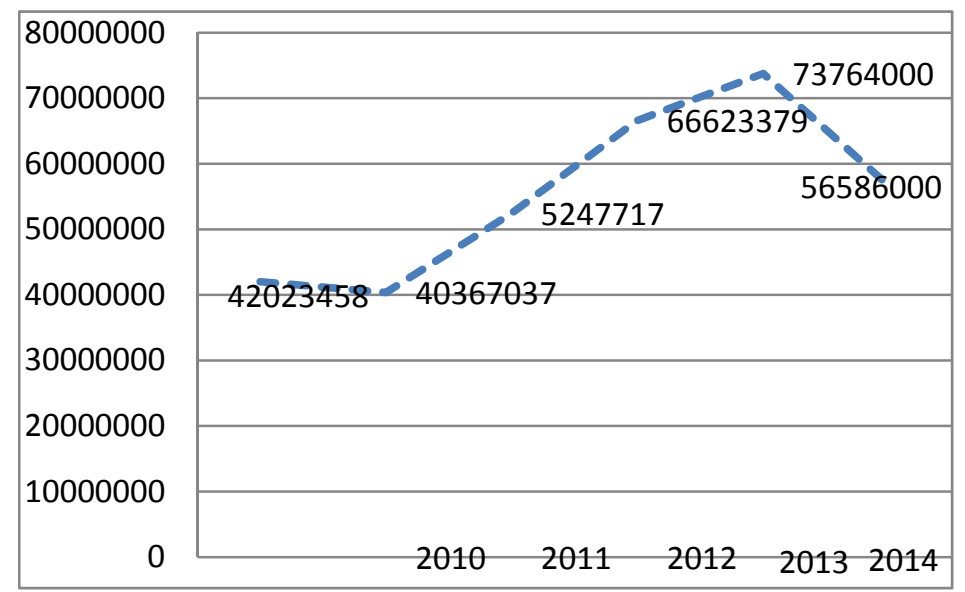

Figure 1. Nowruz trips during 2010-2014 (Source: Cultural Heritage and Tourism Organization)

\subsubsection{Marriage}

In Qajar Era, choosing spouse was taken place in two ways: A common way was to determine the fiancée when they were adolescent or even child (Gobineau, 1859), and the other way was to send a Khastegar (proposer) to the girl's home. Meanwhile matchmakers had an important role in this process (D'Allemagne, 1911). Often matchmakers arranged the marriage through praising the two parts (Wills, 1990). Besides the matchmaker paved the way for meeting between bride and groom which was forbidden according to the traditions (D'Allemagne, 1911). After reaching an agreement about the conditions of wedding, the ceremony was conducted by Shirinikhoran Ceremony in which groom presented a piece of cloth and a wedding ring to Bride (Wills, 1990).

After Shirinikhoran, the ceremony of Aghd (getting betrothed) was held by attending the families of both sides (Holtzer, 1978) which were accompanied by celebration and dance. After passing the intervals between Aghd and wedding which were different in different families, the wedding ceremonies were conducted in stages like Hanabandan ${ }^{\text {Note }} 8$ (Polak, 1990), (Holtzer, 1978), getting bath by the groom, groom's clothes ceremony ${ }^{\text {Note } 9}$ (D'Allemagne, 1911), (Polak, 1990), and taking the bride to the groom's house.

The ethnic groups and minorities had their own customs for marriage ceremonies. For example, Wood Dance and riding and shooting were done among Lur ${ }^{\text {Note }} 10$ tribes' magnificent customs (Wilson, 1969). Also Sarandaz ceremonies for the bride were conducted among Lur tribes which were very interesting. In the ceremony, the groom accompanied by a group of horsemen went for welcoming the bride. One of horsemen stole the scarf of the bride. The bride's companions tried to bring back the stolen scarf, and the groom prevented them from doing it (D'Allemagne, 1911). Wedding ceremonies have changed drastically from Qajar Era until now. We can point out the following items as instance:

a) Reducing parents' role in choosing spouse.

b) Reducing marriage intervals and increasing of its formalities.

c) Increasing Mahr (amount of money or gold given to the bride as a guarantee).

d) Increasing the age of marriage.

One of the most significant issues raised by the travelers regarding marriage was the lack of acquaintance between couples before marriage. They propounded that the girls and boys did not intervene in choosing their spouse and nobody paid attention to their consent (D'Allemagne, 1911), (Moser, 1978). But nowadays the parents are marginalized in this regard. Often the youth want to choose their spouse, and they rarely accept to marry by matchmakers and according to traditional criteria. Nowadays women participate more in society, technology and modernization change societies, and media and mass communication instruments change the views of young generation effectively. Nowadays a part of marriages are done through internet and dating websites (Chaboki, 2011).

Reduction in the duration of the ceremonies is another change in present time. The Contemporary Era, many customs have been vanished or marginalized. For example, Aghd cloth is opened nowadays in a formal way or it is used for decoration. Usually the main Aghd is done by attending elders, and a celebration is held at home or in a wedding salon (Biyok Zade, 2012). Nowadays due to living in small apartments and lack of enough space, most of 
the Iranians hold their ceremonies in wedding salons. Patakhti, and Hanabandan are also very weak and many young couples neglect it.

We should pay attention to the point that in spite of decreasing the duration of ceremonies, their costs have increased immensely. The amount of formalities and luxuries has increased in different customs in a way that enthusiasm and inclination towards marriage is diminishing among the youth (Mofidi, 2011). Jahizieh which was presented by the bride's family as a gift for satisfying needs and beginning a new life nowadays has become a serious obstacle for marriage in most of the regions of Iran due to modernization and increasing expectations and social snobbery (Taleghani, 2009). Increasing education and improvement of women's status in the society accompanied by their economic independence have culminated in increasing expectations and distancing from simple lifestyle of Iranian people. This issue is one of the reasons for increasing the age of marriage among the youth.

The marriage customs of different Iranian ethnicities have changed in some ways but many of their observances are still prevalent. For example, the custom of stealing the cloth of the bride by the groom and wood dance of Bakhtiaris and racing and shooting matches which were appraised by travelers still exist (Ghorbanzade, 2009), (Mirnia, 1991). As a matter of fact, the developments of modern world have been accelerated in the Iranian industrial cities, and Ancient customs are more alive among ethnicities, minorities and villages.

\subsubsection{Customs of Child Birth, and Circumcision Celebration}

In Qajar Era, the ceremonies of child birth had its own observances, including celebration for child birth (D'Allemagne, 1911) (Rice, 1976). Child Naming Ceremonies (D'Allemagne, 1911), and Circumcision Celebration (khatanesooran) (Polak, 1990). But nowadays these customs have decreased drastically. Today young parents name their children independently. Furthermore most of children are mutilated (khatane) in doctor's office so there is no need for gathering family members. Also most of houses have bathrooms and there is no need for inviting elders and taking mother and child to outside baths. We mean the new social conditions have caused the gradual abandonment of these customs in Iranian society (Shakoori \& Azad Armaki, 2003).

\subsubsection{Ghorban Celebration}

Ghorban Celebration which is the memorandum of Abraham's obedience of god for sacrificing his son Ishmael was held in Qajar Era. In this day, each Muslim sacrificed a sheep given their financial capabilities. In Tehran, according to Shah's command, a camel was sacrificed in Negarestan Square. The camel was decorated several days before and was circulated in the city. People paid some money for this camel as their religious donations (Yate, 1987). In the celebration day, the camel was brought to the main square accompanied by military music, soldiers, servicemen and a prince missioner for doing sacrificing. After separating the decorations of the camel, the prince cut its throat and the others cut the meat into pieces. Then the representatives of every social class took his class's portion from this meat (Fraser, 1968), (Polak, 1990). After doing the ceremonies of Ghorban, the ceremonies of Ghorban's salute was held in the king's palace during which the king congratulated the feast to all by holding celebration and feast (Orsolle, 1974). Ghorban is still one of formal celebrations of Iranians which is held in different places of Iran according to particularities of each region (Doosti, 2013). According to a journal Farhange Mardom (2007), Ghorban Celebration is held like Qajar Era in Kashan in 1974 by sacrificing a camel. Nowadays Iranian people hold Ghorban Pray and sacrifice sheep instead of camel. Besides, in some areas, people buy sweets and nuts, and visit each other (in Kurdistan, Turkmenistan, Shiraz and Baluchistan). In some regions, people ornament the sacrificing animal in Kerman and Shiraz (Iranian News Site, 2013).

\subsubsection{Ghadir Celebration}

In Qajar Era, people held Ghadir Celebration. Iranian Shiites visited the Sadat (offspring of Prophet Muhammad) and reitErated their brotherhood i.e. they decided to be friends like brothers (Brugsch, 1990). Nowadays people visit the Sadat and gather in mosques and the Sadat's homes and hold celebrations and Mowludi (religious songs for the birth of Prophet Muhammad).

\subsubsection{Fetr Celebration}

Fetr celebration is held at the end of month Ramadan and beginning of month Shawwal. Fetr means eating and drinking. Due to this reason, this day in which people can eat and drink again after a month, is called Fetr (Mirfatah, 2011).

\subsubsection{Muharram}

Muharram Mourning were held gloriously in Qajar Era. Several weeks before Muharram, people decorated the walls of mosques and temples with black flags and prepared them for holding the ceremonies in a better condition (Brugsch, 1990). In this month, different groups of mourners were made and people gathered in mosques for 
religious mourning anthems. If there was no mosque, a tent was pitched and people mourn there. Sometimes people held the ceremonies in their yards and welcomed their guests with tea and tobacco (Serena, 1984), (Aubin, 1984). Women also participated in the ceremonies by movement at the end of mourning groups, standing at the roofs of houses, and attending at religious mourning ceremonies (Serena, 1984), (Loti, 1922). Besides, some people cut their heads with swords in order to show their hugeness of sorrow ( Hardoui, J. 1922), (Aubin, 1984), (Forbes - Leith, 1988) In this era, Ta'zieh ${ }^{\text {Note }} 11$ show was performed, and men and women attended in these ceremonies extensively (Yate, 1987) (Serena, 1984).

Nowadays Muharram Ceremonies are held in the same way but the form and place of holding the ceremonies have changed (Tabatabaee, 2011). Like Qajar Era, no cheerful ceremonies are held in this month. Turkmen entitle Muharram Bosh Ay i.e. the "joyless month" (Hosseinzade, 2000). People prepare themselves for holding Muharram Mourning. For example, they dust the mosque of their neighborhood, buy chains and black suits, prepare the tools of Nazri (charity foods) (Rezaee, 2000), cover the main stem of Alam (pioneering set of lights installed on a metal structure) with donated clothes (Mirshokraee, 2000), and installing black clothes and flags on mosques (Rezaee, 2000).

In most of Iranian regions, in every town and neighborhood, different mourning groups do the ceremonies like hitting themselves by chains and singing religious mourning anthems. Also Alamatgardani is prevalent in different regions of Iran. Usually Alam is carrying in front of the mourning group (Anasori, 2003).

We also should pay attention that although mourning observances have roots in very old past but in every Era they have changed apparently (Ghasimi, 2010). For example, the symbolic aspects of religious mourning have been reinforced and new motifs have been added which are affected by modernity and technology advancements. Music instruments are modernized, clothes are being changed regularly, some sentences are written on vehicles, and charity foods are distributed in one time consumption dishes (Mohammadi, 2011).

\subsubsection{Mourning Ceremonies}

In Qajar Era, when somebody died, people announced it by reading Quran on the roofs of houses (Wills, 1990), (D'Allemagne, 1911). After funeral, the dead body was taken to cemetery (D'Allemagne, 1911).

In the cemetery, attendants prayed for the dead body and buried it. After funeral, they came home and held funeral ceremonies in the dead man's home for three days (Serena, 1984). Next ceremonies held in the seventh and fortieth night after the death (Willes, 1985). Also after mourning which was usually forty days, some people helped the family of dead person to take off their black clothes and end the mourning period (Wills, 1990), (D'Allemagne, 1911).

Nowadays all of these customs including funeral, washing the dead body, covering the dead body with white clothes, burying the dead body, and reading Quran to the end are still prevalent in most of Iranian regions (Parsa Pazhooh, 2011). But these customs have gradually changed and in great cities including Tehran, some of them are being held weakly or even vanished. In some parts of Tehran, there are not any queues for funeral. On the other hand, funeral ceremonies have declined and a growing number of families do not hold the seventh, fortieth and anniversary memorandum of the death which was prevalent in Qajar Era (Kalantari \& Taslimi Tehrani, 2013).

\subsection{The Factors Affecting the Trajectory of Changing Customs}

According to Arjun (2010), the factors of cultural change include environmental, biological, demographical, technological, cultural, ideological and psychological factors. But the authors of this research have tried to develop their study within the framework of Arjun's theory, and categorize the factors in a native way.

\subsubsection{Geographical Factor}

Iran is a territory that enjoys a specific geographical position and high strategic status historically. Iran has rich resources of wealth and oil, gas, coal and other mines. In Qajar Era, European powers noticed Iran due to its specific position for reaching India and Afghanistan, and particularly its oil sources. Consequently a great number of Europeans came to Iran and Iranians familiarized with the culture and civilization of other countries and cultural changes started in this era.

\subsubsection{Biological Factor}

From Qajar Era on, Iran's demographical structure has changed drastically. The number of educated and employed women increased and urbanization expanded that changed the demographical structure and lifestyle of Iran. One of these changes is that women's marriage age is increasing. 


\subsubsection{Cultural Factor}

One of main factors of social change is the cultural indicator. Culture is a series of language, religion, literature, art, beliefs and values of a society. There is the possibility of cultural interchange as the result of communications among different societies. These elements gradually change the culture and customs of societies. For example, they may change the types of foods, clothes, celebrations and mourning in cultural interactions.

\subsubsection{Demographical Factor}

In recent centuries, migration from villages to cities has drastically increased. This phenomenon has a direct relationship with marginalization because the villagers migrate to cities seeking better profession and position but as they do not have the possibility of living in city centers inhabit in margins and cheaper regions. On the other hand, urbanization impacts on culture because urban life has more difficulty in comparison to rural life. Therefore people have not enough time and energy for dealing with observances and customs. The issue culminates in neglecting and gradual vanishing some of these customs.

\subsubsection{Technological Factor}

Iranian society has moved towards industrialization as the result of increasing population and knowledge. Obviously, the growth of urbanization and industrialization has an impact on job structure, social competition and the number of family members. The growth of women attendance in contemporary society, their independence, their tendency towards working market and employment are some examples of these developments that have changed the belief system and family lifestyle.

\subsubsection{Ideological Factor}

Ideologies including religious, social and political ones have the potential of creating fundamental changes in social structure and relations. For instance, Islam has been the dominant religious ideology in Iran from Qajar Era. This ideology impacts on family relations, kinds of mourning, religious celebrations and so on. One of the factors that mourning for Imam Hussein (PBUH) has endured until now is the Islamic ideologies.

\subsubsection{Psychological Factor}

Psychological factors may change the viewpoints of people regarding their lifestyle i.e. they can change people's view regarding family regulation, providing life instruments, ethnic system, women's education and their participation in social and political affairs, division of labor and so on. Eventually they can change culture and customs.

\subsubsection{Economic Factor}

Economic conditions of Iran have worsened in recent decades. Iran was engaged in war with Iraq for eight years. After the war, Iran was dealing with reconstructing the war consequences. In recent decade, the Western powers have imposed sanctions due to Iran's nuclear program and after that inflation rate increased immensely. Besides, globalization has worsened the situation and has caused people incline towards formalities and luxuries. In old times, Iranian people had a simple life. Therefore most of ceremonies were held for a long time but nowadays many details of customs have been neglected to many formalities and huge costs. This factor has culminated in gradual omission of these customs from Iranian culture.

Of the other factors impacting on Iranian customs are political developments. Some studies have proven this claim (Esmaeeli, 2000). Esmaeeli has regarded the political changes and executive management of society as the factors for cultural change. He means that the type of government dominated on Iran may impact on cultural change or endurance. As the result of Qajar decline and dominance of Reza Shah, ethnic identities and religious values weakened. Pahlavi Regime banned local clothes, imposed western clothes and bowler hats, banned Islamic veils, banned camel sacrificing for Ghorban, and restricted Muharram mourning (Nasrpoor, 2005). Reza Shah confronted Islam through these actions and violated religious observances and customs.

Islamic Revolution brought back religious values to sociopolitical life of Iranian society (Dehghani Firoozabadi et al, 2013). Consequently a government took power that was consistent with people's beliefs. So this is one of the reasons for enduring of religious customs until now. Figure 2 shows the factors affecting on cultural change from the viewpoints of researchers. 


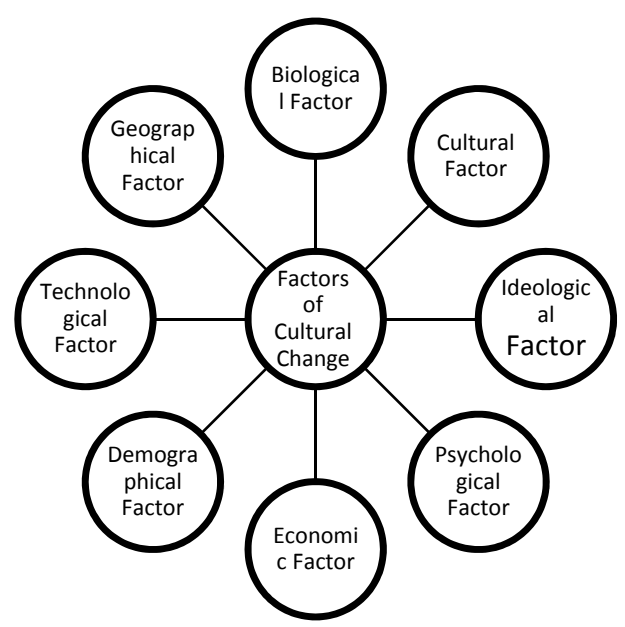

Figure 2. Factors of Cultural Change

\subsubsection{Impact of Globalization on Socio-Cultural Changes}

One of the significant factors in cultural change of societies is globalization. Globalization has vanished spatial and time distances by using communication revolution (new technologies such as internet, satellite, telephone, optic cables and fax machines) and it has integrated different parts of the world (Vasegh, 2004). Actually globalization is a multi-dimensional process that creates deterritorialization of national borders, spread of ties among societies, and the growth of communications in different contexts of economy, politics and culture(Ghasemi \& Nazeri, 2012). Globalization is regarded as the most significant factor in cultural changes through removing limits and expanding communications among societies.

Globalization's impact on culture has two aspects and there are different theories about it. On the one hand, some thinkers believe that globalization encourages the culture of domination, undermines the role of native and local cultures, and under effect of global mass communication forms a world culture which is usually the culture of dominance and consumerism (Beyran, 2003). In fact, this issue will culminate in integrating the cultures of developing societies and their cultural assimilation. On the other hand, some thinkers believe that globalization has created an opportunity for local and native customs and observances with historical and religious roots to exploit the opportunity of globalization so that they attract the attention of other nations to their cultural contents (Dehghanifiroozabadi et al, 2013).

Globalization's impact on every culture depends on the features and elements of that culture. The cultures of different societies may be categorized into two groups: particularistic and generalist. Particularistic culture has some features and elements which is specific and respected by the members of that society. The values of this kind of culture are respected only by limited groups and societies. But generalist culture has some features which are respected by different groups across the world. Consequently their values have a general and universal influence (Ghasemi \& Nazeri, 2012). In globalization process, generalist cultures can adopt themselves to global conditions and endure. But particularistic cultures may be undermined or vanished in confrontation with this phenomenon.

For example, Nowruz Celebration is a national observance but it enjoys general and universal values and features that have caused its generality in the age of globalization, including ethical values, emphasizing reinforcement of human relations, paying attention to environment and hygiene and health. Also Ta'zieh (religious mourning) has universal potential as one of the symbols for braveness. We observe the success of this cultural symbol at global level. In fact, we can say that in globalization process, some cultural components cannot resist against it and they will be vanished (Dehghanifiroozabadi et al, 2013), and some of them will be propounded at world level.

\section{Discussions}

Some studies have been done on itineraries about Iran which can be divided into three main sections:

1) Books which cataloged itineraries' titles and or titles of sections of each itinerary which are known as descriptive list such as Poorahmad Jaghdachi (1977), and Babazade (1979). These categorizations of books have some defects, they mostly did not include other itineraries written or printed after them. Also, these resources are limited to itineraries presented in a particular library and does not include all of the itineraries. Moreover, they 
have not described or analyzed materials inside each itinerary from the content point of view and have concise and general view.

2) Studies that notice one or two specific subjects in each itinerary and mostly discussed those subjects. For example Eshraghi (2000) has described Esfahan incidents, Lorestani (1998) Lorestan situation, and Mehradadi (2000) Iranian Women from foreigner itinerary writers' point of view.

3) The studies that generally discussed itineraries and their contents regarding culture and society of Iran. Farooghi (1983) discussed some of the most important and famous itineraries of Europeans, Iranians and Muslims, and described some of them in a nutshell critically. Ayati (1996) in his studies in Shiraz University analyzed and evaluated positive and negative traits of Iranians during Qajar Dynasty such as behavior, hospitality, superstitions and etc. from well-known European globetrotters' opinions. Golzade Asgari (2006) studied social situation of Tehran city in Naseri Era from European travelers' point of view which only one chapter of his book is assigned to customs and tradition of Tehran's people in Qajar Era.

Itineraries have significant importance because they were written in some periods of Iran's history that most of historical texts were written under supervision of courts and governments and were full of falsifications and unrealistic flatteries. Besides, itineraries contain vast political, social, cultural, and customs information which are very important information source for studying cultural-social situation of Iran in that period. Moreover, this studies surveying evolution of customs and society in different period of time from outsiders of this cultural set point of view. While writing costumes and traditions by a foreign author, its advantages and disadvantages appear more clearly because itinerary authors had not prejudice about customs and just write whatever they saw. In this process, maybe tourists could write lots of issues which were not considered by locals or became ordinary because of repetition. Also significance of this study is clearly determined noticing culture's place in social life and application of customs in various aspects of life such as nurturing new generation, and forming family, official and unofficial relations.

As this research is based on travelogues, and the writers of them were not professional historians, it is probable that their personal views and preferences affected registering historical happenings. Besides, the authors of this research were confronted with limitation of resources for writing the contemporary customs due to the lack of scientific books and articles in this regard.

\section{Conclusion}

In this research, travelers' views and reactions regarding celebrations and mourning of Qajar Era were illustrated. Some Iranian customs have been praised by travelers and some others are criticized by them. The reasons for their critical views include: they resided in Iran for a short time; they did not know Farsi language; they did not have a correct knowledge about Iranian religious issues; they compared Iranian culture with their own cultures in biased ways; and they did not attend among different social classes in order to confront different customs.

On the other hand, European travelers have provided more conclusive explanations about some of these customs and neglected some others. This issue has a direct relationship with the position of these customs in Qajar society i.e. the travelers dealt more with the more important customs in Qajar Era and the marginal customs were neglected. Most of customs related to celebrations and mourning have changed immensely from Qajar Era so far. In these changes we observe gradual omission of some details of these customs and inclination towards formalities and luxuries. In relation with the reasons for these cultural developments, various factors were mentioned, including political, economic, geographical, demographical, psychological, ideological and cultural factors and also the phenomenon of globalization. Given the vast relationship among different societies and cultural interaction which is affected by communication revolution and increasing media consumption, the phenomenon of globalization was identified as the main factor for cultural change.

For future study, the researchers recommend having a comparative study of political-cultural impacts of Safavid and Qajar in European travel diaries.

\section{Acknowledgement}

I appreciated Dr. H. Raznahan who checked all research notes during this study. I am also indebted to Dr. S. Yazdani who replied to all related questions. I wish to thank, Dr. M. Khalkhali who provide many research materials.

\section{References}

Ahmadi, M. (2011). An Overview on Nowruz Cermony and Tradition. Iran: Rostam and Sohrab. 
Anasori, J. (2003). Ashura Description and Aba Abdollah Hossein Mourning Traditions in Iran. Tehran: Zarin \& Simin.

Arjunan, N. K. (2010). Philosophical and Sociological Bases of Education, Palakkad (2nd ed.). Palakkad: Yuga Publications.

Aubin, E. (1984). In A. A. Saeedi (Trans.), La Perse d Aujourd Hui Iran Mesopotamie. Tehran: Zavvar.

Ayati, M. (1996). Travelling Through Itineraries in Qajar Era (Master). University of Shiraz.

Babazade, S. (1979). List of Germany's Itineraries in Iranian National Library. Tehran: National Library of Iran.

Bahrami, A. (2005). Iranian Cermonies (Vol. Daftare Pazhooheshhaye Farhangi). Tehran.

Beyran, S. (2003). Satellites, Globalization and Identity Crisis. Pazhooheshhaye Ertebati (pp. 30-31), 134-135.

Biyok Zade, S. (2012). Mariage in Iranian Method. Tehran: Tarfand.

Brugsch, H. K. (1990). In M. H. Kordbacheh (Trans), Reise Der K. Preussischen Gesandtschaft Nach Persien (Vol. 1,2). Tehran: Etelaat.

Chaboki, R. (2011). Sadness and Happiness of Marriage. from Soroosh.

Custom. (2015). In Wikipedia, the free encyclopedia. Retrieved January 9, 2015, from http://simple.wikipedia.org/wiki/Custom

D'Allemagne, H. R. (1911). In G. Samiee (Trans), Du Khorassan au Pays des Backhtiaris : trois Mois de Voyage en Perse (Vol. 1,2). Tehran: Tavoos.

Dehghanifiroozabadi, J. (2013). Cultural Globalization and Cultural Security. Tehran: Pazhooheshgahe Farhang, Honar va Ertebatat.

Doosti, S. (2013). Ritual Reflections of Ghorban Feast in People Culture. Farhang-e-Mardome Iran, 1(22), 56.

Eshraghi, F. (2000). Isfahan in Foreign Travelers' Prespective. Esfahan: Atropat.

Esmaeeli, R. (2000). Culture and Cultural Changes. Farhange Esfehan, 39, 41.

Farhange Mardom. (2007). Ghorbani Shotor Dar Kashan (19, 20), 131-133.

Farooghi, F. (1983). Travelling Through ItinEraries. Tehran: Ataee.

Feuvrier, J. (1990). In A. Eghbal ashtiyani (Trans.), Rois Ans a la Cour de Perse. Tehran: Donyaye Ketab.

Flandin, E. N. (1851). In H. Noor sadeghi (Trans.), Voyage en Perse. Tehram: Naghshe Jahan.

Forbes-Leith, F. A. C. (1988). In H. Abootorabian (Trans.), Chechmate: Fighting Tradition in Central Persia. Tehran: Ettelaat.

Fraser, J. B. (1968). In M. Amiri (Trans.), A Winter's Journey (Tatar)from Constantinople to Tehran. Tehran: Toos.

Ghasemi, H., \& Nazeri, Z. (2012). Iranian Culture in the Globalization Era Farhang and Ertebatat, 13(51), 91, 101, 104.

Ghasimi, R. (2010). Iranian Identity Factors in Nowruz, Ghorban Feast, and Moharam Mourning (Master), Iranian Studies Center, Tehran.

Ghorbanzade, M. R. (2009). The Marriage Traditions in Iran and Other Countries. Langerood: Faghihi.

Gobineau, J. A. (1859). Trois and En Asie (De 1855 A 1858) (Z. A. Mansoori, Trans.). Tehran: Farrokhi.

Golzade Asgari, R. (2006). Society in Qajar Era According to Europeans' Itineraries (Master), Imam Khomeyni International University.

Grothe, H. (1991). In M. Jalilvand (Trans.), Wanderungen in Persien. Tehran: Markaz.

Hardoui, J. (1929). In M. Mohazzab (Trans.), Au Soleil Perse. Iran: Chehreh.

Holtzer, E. (1978). In M. Asemi (Trans.), Persien vor 113 Jahren. Tehran: Markaze Mardom Shenasi Iran.

Hosseinzade, F. (2000). Moharam and Nation Unity. Journal of Moharam and Iranian Cultures Conference, 1, 34.

Jafari Nia, M. R., \& Yegane, A. B. (2014). Feasts and Festivals. Qom: Qasime Kosar.

Kalantari, A. (2013). Ghorban Festival's Customs in Different Cities of Iran. from Iranian News Site 
Kalantari, A., \& Taslimi Tehrani, R. (2013). An Evaluation on the Mysteriousness of Death in Tehran. Marefate Farhangi and Ejtemaee, 4(3), 122.

Lorestani, M. A. (1998). Lorestan in Foreign Travelers' Itineraries. Tehran: Fekre Rooz.

Loti, P. (1922). In B. A. D. Ketabi (Trans.), Aus Persiens Wunderwelt; Erste Bis Sechste Auflage Mit 16 Ganzseitigen Bildern. Esfehan: Naghshe Jahan.

Mehradadi, M. (2000). Iranian Women According to Foreigners 'Itineraries. Tehran: Afarinesh.

Mirfatah, M. (2011). Iranian Cermony and Traditions From Past Till Now. Tehran: Alamgir.

Mirnia, A. (1991). Iranian Culture. Tehran: Parsa.

Mirshokraee, M. (2000). Moharam and It's Symbols. Journal of Moharam and Iranian Cultures Conference, 1, 15.

Mofidi, T. (2011). Marriage the Most Holiness Moment of Life. From Jame Jam.

Mohammadi, H. (2011). Impact of Modernity on Mourning. From Setare Sobh

moser, H. (1978). In A. Motarjem (Trans.), A Trevers L'asle Centrale. Tehran: Sahar.

Nasrpoor, M. A., \& Nazeri, A. (2005). Role of Statesmen in Changing the Political Culture of Society. Qom: Islam Qom.

Norden, H. (1978). In S. Samiee (Trans.), Under Persian Skies: A Record of Travel by the Old Caravan Routes of Western Persia. Tehran: Tehran University.

Orsolle, E. (1974). In A. A. Saeedi (Trans.), Le Caucase et la Perse. Tehran: Zavvar.

Parsa Pazhooh, S. (2011). Customs' Anthropology and Ways of Death and Life from Andishe Iranshahr.

Polak, J. E. (1990). In K. Jahandari (Trans.), Persien: Das Land Und Seine Bewohner: Ethnographische Schilderungen. Tehran: Kharazmi.

Poorahmad Jaghdachi, M. T. (1977). List of British's Itineraries in Iranian National Library. Tehran: National Library of Iran.

Rezaee, M. (2000). Moharam Mourning in Ardabil. Journal of Moharam and Iranian Cultures Conference, 1, $152-156$.

Rice, C. C. (1976). In A. Azad (Trans.), Persian Woman \& Their Ways. Tehran: Ketabdar.

Richards, F. C. (1931). In M. D. Saba (Trans.), A Persian Journey; Being an Etcher's Impressions of Middle East. Tehran: Bongahe Nashr ve Chape Ketab.

Rooh Al Amini, M. (1998). Traditional Customs and Cermonies in Contemporary Iran Tehran: Agah.

Serena, C. (1984). In A. A. Saeedi (Trans.), Hommes et Choses en Perse. Tehran: Zavvar.

Shabani, R. (2001). Nowruz Custom and Tradition. Tehran: Al Mahdi.

Shakoori, A., \& Azad Armaki, T. (2003). Modernity and Iranian Family. Department of Literature and Humanities (Esfehan University), 2(11), 261.

Shiel, M. L. (1984). In H. Aboo Torabiyan (Trans.), Glimpses of Life and Manners in Persia. Tehran: Nashre no.

Tabatabaee, L. (2011). Moharam Mourning Custom in Ardibians' Culture. Tehran: Behin.

Taleghani, M. (2009). Dowry, Cause of Sadness or Happiness. from Resalat

Vasegh, M. (2004). Globalization: Results and Consequances. Tehran: Pazhooheshkade Motaleat Rahbordi.

Wills, C. J. (1990). In G. H. Gharagoozloo (Trans.), In the Land of the Lion and Sun Or, Modern Persia, Being Experiences of Life in Persia During a Residence of Fifteen Years in Various Parts of That Country from 1881 to 1866. Tehran: Eghbal.

Wilson, A. T. (1969). In H. S. Noori (Trans.), S.W. Persia: Letters and Diary of a Young Political Officer. Tehran: Vahid.

Yate, C. E. (1987).In G. R. ZafEranloo \& Mehrdad, (Trans.), Khurasan and Sistan. Tehran: Yazdan.

\section{Notes}

Note 1. Nowruz is the traditional Iranian festival of spring which starts at the exact moment of the vernal equinox, commencing the start of the spring. It is considered as the start of the New Year among Iranians. 
Note 2. It is a ceremony which held after baby's circumcision, and all guests bring some gifts for the newborn children.

Note 3. The mourning of Muharram marks the anniversary of the Battle of Karbala when Imam Hussein ibn Ali, the grandson of Muhammad, and a Shia Imam, was killed by Yazid I at Karbala.

Note 4. Dervish or Darvesh is a person who treats as a Sufi Muslim ascetic path and known for their extreme poverty and austerity.

Note 5. In Iranian Shi' ism it is a kind of passion play on the tragic fate of Hussein (the third Muslim Imam).

Note 6. Qama Zani is an act of mourning by some of Shi'i Muslims for their third Imam Hussein Ibn Ali.

Note 7. Iranian called it Sizde- Bedar.

Note 8. This ceremony held as a symbol of Bride's goodbye to her family, one night before wedding ceremony.

Note 9. This is a ceremony in which bride's family give new cloths to Groom as a gift.

Note 10. Lurs or Lors are an Iranian people who mainly live in south-western of Iran and speak the Luri language.

Note 11. In Iranian Shi' ism it is a kind of passion play on the tragic fate of Hussein (the third Muslim Imam).

\section{Copyrights}

Copyright for this article is retained by the author(s), with first publication rights granted to the journal.

This is an open-access article distributed under the terms and conditions of the Creative Commons Attribution license (http://creativecommons.org/licenses/by/3.0/). 